\title{
A study on relevance of mid arm circumference measurement among 13-60 months of children at urban field practice area of Alluri Sita Ramaraju Academy of Medical Sciences, Eluru
}

\author{
Thotakura Praneeth Choudhary ${ }^{1}$, K. Chandra Sekhar ${ }^{2} *$ K. Uma Maheshwara Rao ${ }^{3}$, \\ Chandrasekhar Vallepalli $^{4}$, P. G. Deotale ${ }^{2}$, Sandhya Sree Gogineni ${ }^{1}$
}

\author{
${ }^{1}$ House Surgeon, Alluri Sita Ramaraju Academy of Medical Sciences, Eluru-534005, A.P., India \\ ${ }^{2}$ Department of Community Medicine, Alluri Sita Ramaraju Academy of Medical Sciences, Eluru-534005, A.P., India \\ ${ }^{3}$ Department of Paediatrics, Alluri Sita Ramaraju Academy of Medical Sciences, Eluru-534005, A.P., India \\ ${ }^{4}$ Post Graduate Student, Alluri Sita Ramaraju Academy of Medical Sciences, Eluru-534005, A.P., India
}

Received: 18 May 2014

Accepted: 22 June 2014

\section{*Correspondence:}

Dr. K. Chandra Sekhar,

E-mail: cskalevaru@gmail.com

Copyright: (c) the author(s), publisher and licensee Medip Academy. This is an open-access article distributed under the terms of the Creative Commons Attribution Non-Commercial License, which permits unrestricted non-commercial use, distribution, and reproduction in any medium, provided the original work is properly cited.

\begin{abstract}
Background: Protein energy malnutrition commonly seen in 2 to 5 years of age group in developing countries like in India. This could be due to lack of awareness about nutritive value of foods, faulty feeding practices, ignorance plays a major role in the development of Protein malnutrition in early ages of life. This leads to hampering of physical and mental development of the child. Objectives of current study were: 1) To know the prevalence of protein energy malnutrition among 13-60 months of children. 2) To determine relevance of mid arm circumference measurement with WHO standards. 3) To study the demographic variables associated with Protein energy malnutrition.

Methods: The present community based cross sectional study was conducted at urban area of Eluru during the period from Sep 2013 to December 2013. A total of 133 individuals were selected from the field practice area of Alluri Sita Ramaraju academy of medical sciences, Eluru. Results were analyzed and necessary statistical tests like proportions and chi square tests were applied.

Results: Out of 133 individuals, the prevalence of severe malnutrition among 13-60 months children was 7.5\%; prevalence of mild to moderate malnutrition was $24 \%$. Among the severe malnutrition individuals, $60 \%$ from labourer occupation. Classification of mid arm circumference of 2-5 years children compared with World Health Organization weight standards, $87.9 \%$ were shown as normal and $70 \%$ matching of results with severe malnutrition individuals.

Conclusion: Based on the above study results, need to give the training to gross root level workers regarding the measurement of arm circumference of children between the age group of 13-60 months children. Still we can consider mid arm circumference is one of the best tool for consideration of protein energy malnutrition detection at the basic level health point and this is cheap, easy and to be detected at early stage of life.
\end{abstract}

Keywords: Age, Sex, Occupation, Mid arm circumference, WHO weight standards

\section{INTRODUCTION}

Globally WHO (2000) estimated malnourished children at 181.9 million (32\%) in developing countries. Protein Energy Malnutrition (PEM) is a serious health problem, approximately $50 \%$ of the 10 million deaths each year in developing countries occurred because of malnutrition in children younger than five years. Despite global efforts to meet the millennium development goal of halving the prevalence of underweight children under 5 by 2015 , underweight rates remain high in large parts of South Asia. ${ }^{1}$ 
Protein energy malnutrition commonly seen in 2 to 5 years of age group in developing countries like in India. In the Population aged 0 to 5 years prevalence in Asia in severe form was $6.6 \%$ and in moderate form was $64.4 \%$. $^{2}$ The most vulnerable period next to infancy is the age of 1-5 years. Preschool children constitute about $14 \%$ of the Indian population. Nutritional status of pre-school children is of paramount importance, since the foundation of lifetime health, strength and intellectual vitality is laid during that period. In developing countries, particularly where the population is high, hunger and malnutrition are wide spread among the preschool age children. ${ }^{3}$

PEM remains an important public health problem in all the states of India. ${ }^{4}$ PEM is major contributory factor in majority of these childhood morbidities and mortalities. Malnutrition is a contributing factor in nearly $60 \%$ of deaths in children for which infectious disease is an underlying cause. ${ }^{5}$ In addition to reliability and simplicity, Mid Upper Arm Circumference (MUAC) has demonstrated superior sensitivity to risk of death. ${ }^{6,7}$

The WHO standards were developed using data from a multi-center international study and, as a standard rather than a reference, describe how children should grow under optimal conditions. They were developed to replace the National Center for Health Statistics (NCHS)/WHO growth reference and represent a significant move forward in the understanding and measurement of the nutritional status of children. ${ }^{8}$

\section{Objectives}

1. To know the prevalence of protein energy malnutrition among 13-60 months of children.

2. To determine relevance of mid arm circumference measurement with WHO standards.

3. To study the demographic variables associated with protein energy malnutrition.

\section{METHODS}

The present community based cross sectional study was conducted at urban area of Eluru during the period from Sep 2013 to December 2013. A total of 133 individuals were selected from the field practice area of Alluri Sita Ramaraju academy of medical sciences, Eluru. Informed consent and institutional ethical committee clearance was taken.

Measurements of height, weight, Mid-Upper Arm Circumference (MUAC) were recorded from the selected children. All measurements were taken three times and an average value was recorded. The scales were checked for accuracy and before taking measurements during the fieldwork. The technique of recording weight, height and MUAC was done according to guidelines suggested by the WHO expert committee (1995).

\section{Mid upper arm circumference (MUAC)}

MUAC was measured with the child's left arm at right angle $\left(90^{\circ}\right)$ to the body. Using a conventional nonstretchable tape, the distance between the inferior border of the acromion and the tip of the olecranon process was measured and the mid-point on the child's arm was marked. The tape was then placed horizontally at the level of the mid-point without compressing the tissues and a circumference measurement was taken to the nearest $0.1 \mathrm{~cm}$.

Normal MUAC for a child between 1-5 years of age is greater than $13.5 \mathrm{~cm}$. If the MUAC is $12.5-13.5$ it was taken as mild to moderate malnutrition and if it is less than $12.5 \mathrm{~cm}$ it is suggestive of severe malnutrition.

\section{Weight}

Salter's baby weighing scale and bathroom weighing machine was used to measure the body weight. Weight was measured without any footwear and with minimal clothing nearest $0.1 \mathrm{~kg}$.

The scale was zeroed before each session. The balance was checked regularly for accuracy using standard weights.

\section{Length/height}

Supine length was measured on all children up to 2 years of age or on all children $85 \mathrm{~cm}$ or less in length. For children older than 2 years or taller than $85 \mathrm{~cm}$, standing height was measured. Standing height was measured without any foot wear to the nearest $0.5 \mathrm{~cm}$ using a standard calibrated bar.

\section{Exclusion criteria}

Children $<13$ months of age and above 5 years of age and children who were critically ill were excluded from the study.

\section{Statistical analysis}

Data was entered and analyzed in Microsoft office excel 2007 and necessary statistical tests like proportions and chi square tests were applied.

\section{RESULTS}

Table 1 depicts, About 42 (31.6\%) out of 133 individuals were having malnutrition.

Table 2 shows that $33.3 \%$ of mild to moderate malnutrition was found to be $<18$ years of age group of mothers.

Table 3 depicts, among illiterate mothers, about $12.6 \%$ of the children were severe Malnutrition individuals. 
Table 1: Age of the children in relation to MAC inference.

\begin{tabular}{|lllll|}
\hline Age (months) & $>\mathbf{1 3 . 5} \mathbf{c m}$ & $\mathbf{1 2 . 5}$ to $\mathbf{1 3 . 5} \mathbf{~ c m}$ & $<\mathbf{1 2 . 5} \mathbf{~ c m}$ & Total \\
\hline $13-24$ & $21(65.6 \%)$ & $10(31.2 \%)$ & $1(3.2 \%)$ & $32(100 \%)$ \\
\hline $25-36$ & $21(65.6 \%)$ & $7(21.8 \%)$ & $4(12.5 \%)$ & $32(100 \%)$ \\
\hline $37-48$ & $26(81.2 \%)$ & $9(28.1 \%)$ & $4(10.2 \%)$ & $39(100 \%)$ \\
\hline $49-60$ & $23(76.6 \%)$ & $6(20 \%)$ & $1(3 \%)$ & $30(100 \%)$ \\
\hline Total & $91(68.5 \%)$ & $32(24 \%)$ & $10(7.5 \%)$ & $133(100 \%)$ \\
\hline
\end{tabular}

Table 2: MAC in relation to age of mother.

\begin{tabular}{|lllll|}
\hline Age $($ years $)$ & $>\mathbf{1 3 . 5} \mathbf{c m}$ & $\mathbf{1 2 . 5}$ to $\mathbf{1 3 . 5} \mathrm{cm}$ & $<\mathbf{1 2 . 5} \mathrm{cm}$ & Total \\
\hline$<18$ years & $8(66.7 \%)$ & $4(33.3 \%)$ & $0(0 \%)$ & $12(100 \%)$ \\
\hline $18-25$ years & $63(70.7 \%)$ & $18(20.2 \%)$ & $8(8.9 \%)$ & $89(100 \%)$ \\
\hline$>25$ years & $20(62.5 \%)$ & $10(31.2 \%)$ & $2(6.2 \%)$ & $32(100 \%)$ \\
\hline Total & $91(68.5 \%)$ & $32(24 \%)$ & $10(7.5 \%)$ & $133(100 \%)$ \\
\hline
\end{tabular}

Table 3: Literacy of mother in relation to MAC.

\begin{tabular}{|lllll|}
\hline Literacy & $>13.5 \mathrm{~cm}$ & $\mathbf{1 2 . 5}-\mathbf{1 3 . 5} \mathrm{cm}$ & $<\mathbf{1 2 . 5} \mathrm{cm}$ & Total \\
\hline Illiterate & $35(55.7 \%)$ & $20(31.7 \%)$ & $8(12.6 \%)$ & $63(100 \%)$ \\
\hline Primary school & $46(79.3 \%)$ & $10(17.2 \%)$ & $2(3.5 \%)$ & $58(100 \%)$ \\
\hline High school & $6(75 \%)$ & $2(25 \%)$ & $0(0 \%)$ & $8(100 \%)$ \\
\hline College & $4(100 \%)$ & $0(0 \%)$ & $0(0 \%)$ & $4(100 \%)$ \\
\hline PG/prof & $0(0 \%)$ & $0(0 \%)$ & $0(0 \%)$ & $0(0 \%)$ \\
\hline Total & $91(68.5 \%)$ & $32(24 \%)$ & $10(7.5 \%)$ & $133(100 \%)$ \\
\hline
\end{tabular}

Table 4 shows that, among agriculture occupation mothers, $18.1 \%$ of children from severe malnutrition individuals.
Table 5 depicts that, among $>2000$ per capita income family, severe malnutrition individuals were only $0.8 \%$. Statistically significant association was found.

Table 4: Occupation of mother in relation to MAC.

\begin{tabular}{|lllll|}
\hline Occupation & $>\mathbf{1 3 . 5} \mathbf{c m}$ & $\mathbf{1 2 . 5}-\mathbf{1 3 . 5} \mathrm{cm}$ & $<\mathbf{1 2 . 5} \mathrm{cm}$ & Total \\
\hline House wife & $12(63.1 \%)$ & $\mathbf{7}(36.8 \%)$ & $0(0 \%)$ & $19(100 \%)$ \\
\hline Labourer & $68(73.9 \%)$ & $18(19.5 \%)$ & $6(6.5 \%)$ & $92(100 \%)$ \\
\hline Agriculture & $11(50 \%)$ & $7(31.8 \%)$ & $4(18.1 \%)$ & $22(100 \%)$ \\
\hline Total & $91(68.5 \%)$ & $32(24 \%)$ & $10(7.5 \%)$ & $133(100 \%)$ \\
\hline
\end{tabular}

Table 5: Per capita income of family in relation to MAC.

\begin{tabular}{|lllll|}
$\begin{array}{l}\text { Per capita income } \\
\text { (rupees) }\end{array}$ & $>\mathbf{1 3 . 5} \mathbf{c m}$ & $\mathbf{1 2 . 5 - 1 3 . 5} \mathbf{c m}$ & $<\mathbf{1 2 . 5} \mathbf{c m}$ & Total \\
\hline $1000-2000$ & $9(47.3 \%)$ & $1(5.2 \%)$ & $9(37.3 \%)$ & $19(100 \%)$ \\
\hline$>2000$ & $82(71.9 \%)$ & $31(27.1 \%)$ & $1(0.8 \%)$ & $114(100 \%)$ \\
\hline Total & $91(68.5 \%)$ & $32(24 \%)$ & $10(7.5 \%)$ & $133(100 \%)$ \\
\hline
\end{tabular}

$\mathrm{X}^{2}=9.2, \mathrm{P}<0.01$ 
Table 6 revealed mean height in the study population was good and proportionally increasing with age.

Table 6: Mean height of child versus age.

\begin{tabular}{|ll|}
\hline Age (months) & Mean height $(\mathbf{c m})$ \\
\hline $13-24$ & 82.18 \\
\hline $25-36$ & 89.9 \\
\hline $37-48$ & 93 \\
\hline $49-60$ & 99.8 \\
\hline
\end{tabular}

Table 7 shows, in the study population, there was no much weight increment between 49-60 months of children.

Table 7: Mean weight versus age.

\begin{tabular}{|ll|}
\hline Age (months) & Mean weight $(\mathrm{kg})$ \\
\hline $13-24$ & 11.6 \\
\hline $25-36$ & 13.3 \\
\hline $37-48$ & 15.4 \\
\hline $49-60$ & 15.5 \\
\hline
\end{tabular}

Table 8 depicts, among mild to moderate malnutrition individuals, about $87.5 \%$ of children measurement of MAC was found to be matched with WHO Standards of weight. Among severe malnutrition individuals, about $70 \%$ of children measurement of MAC with WHO standards of weight.

Table 8: MAC versus WHO standards of weight.

\begin{tabular}{|llll|}
\hline MAC (cm) & $\begin{array}{l}\text { WHO } \\
\text { standards } \\
\text { within limits }\end{array}$ & $\begin{array}{l}\text { WHO } \\
\text { standards } \\
\text { outside the } \\
\text { limits }\end{array}$ & Total \\
\hline$>13.5$ & $80(87.9 \%)$ & $11(12.1 \%)$ & $91(100 \%)$ \\
\hline $12.5-13.5$ & $28(87.5 \%)$ & $4(12.5 \%)$ & $32(100 \%)$ \\
\hline$<12.5$ & $7(70 \%)$ & $3(30 \%)$ & $10(100 \%)$ \\
\hline Total & $115(86.5 \%)$ & $18(13.5 \%)$ & $133(100 \%)$ \\
\hline
\end{tabular}

Table 9 shows, among mild to moderate malnutrition individuals, about $87.5 \%$ of children measurement of MAC was found to be matched with WHO Standards of height. Among severe malnutrition individuals, about $90 \%$ of children measurement of MAC with WHO standards of height.

Table 9: MAC versus WHO standards of height.

\begin{tabular}{|llll|} 
MAC (cm) & $\begin{array}{l}\text { WHO } \\
\text { standards } \\
\text { within limits }\end{array}$ & $\begin{array}{l}\text { WHO } \\
\text { standards } \\
\text { outside the } \\
\text { limits }\end{array}$ & Total \\
\hline$>13.5$ & $70(77 \%)$ & $21(23 \%)$ & $91(100 \%)$ \\
\hline $12.5-13.5$ & $28(87.5 \%)$ & $4(12.5 \%)$ & $32(100 \%)$ \\
\hline$<12.5$ & $9(90 \%)$ & $1(10 \%)$ & $10(100 \%)$ \\
\hline Total & $107(80.5 \%)$ & $26(19.5 \%)$ & $133(100 \%)$ \\
\hline
\end{tabular}

\section{DISCUSSION}

Mid arm circumference is one of the measure of protein energy malnutrition. In the present study, 133 children of 13 to 60 months of age were studied. In the present study, based on MAC measurement, mild to moderate malnutrition was found to be $24 \%$ and severe malnutrition was found to be $7.5 \%$. The prevalence of malnutrition was $31.6 \%$ in this study, where as it was $50.46 \%$ in a study done by Avachat SS et al. ${ }^{9}$ As mentioned by Gupta et al. ${ }^{10}$ pre-school children are notoriously fraught with the risk of malnutrition and the prevalence of malnutrition varies between $50-80 \%$.

Dattatraya et al. ${ }^{11}$ showed prevalence of malnutrition among Anganwadi children was $49.1 \%$, and in Verma et al. $(2007)^{12}$ PEM was $48.7 \%$ and it was $26.83 \%$. by Harisankar et al. (2004). ${ }^{13}$

About $33.3 \%$ of mild to moderate malnutrition was found to be $<18$ years of age group of mothers. There was statistically significant association was found between $>2000$ per capita income versus malnutrition. Similar findings were observed in a study done by Gupta et al. ${ }^{10}$ Among illiterate mothers, about $44.3 \%$ of the children were having malnutrition, similar findings were seen with Dattatraya et al. ${ }^{11}(51 \%)$, whereas it was $70 \%$. By Verma et al. $(2007)^{12}$ and $86.2 \%$ by Ahmed E et al. ${ }^{14}$

Study done in Chandigarh shows that, with increase in educational status of parents, the prevalence of PEM was steadily and significantly decreases $(\mathrm{P}<0.001) .{ }^{15}$ Similar findings in a study done in Kanpur. ${ }^{16}$

Joshi et al. ${ }^{17}$ showed that poor socio-economic status and poor housing and environmental conditions significantly contributed to PEM. National family health survey-3 revealed that $46 \%$ of children in India are affected with PEM. In our study $36.8 \%$ of malnutrition was seen in children of housewife by occupation, where as it was $48.1 \%$ by Dattatraya et al. ${ }^{11}$

Among mild to moderate malnutrition individuals, about $87.5 \%$ of children measurement of MAC was found to be matched with WHO Standards of weight. Among severe malnutrition individuals, about $70 \%$ of children measurement of MAC with WHO standards of weight.

\section{CONCLUSION}

Based on our study results, age at marriage of mothers and per capita income of the family to be increased. Health and nutrition Education is necessary for mothers regarding good household maintenance and maintaining proper hygienic measures. Mid arm circumference measurement was simple and easy to measure and cost effective method in community for early detection of malnutrition and reliability of test is also matching with WHO standards of weight and height. 
Funding: No funding sources

Conflict of interest: None declared

Ethical approval: The study was approved by the institutional ethics committee

\section{REFERENCES}

1. Pedro Sanchez, M. S. Swaminathan, Philip Dobie, Nalan Yuksel. Halving hunger: it can be done. In: Pedro Sanchez, M. S. Swaminathan, Philip Dobie, Nalan Yuksel, eds. UN Millennium Project. New York: Task Force on Hunger; 2005: 1-32.

2. The Economist. Putting the smallest first, 2010. Available http://www.economist.com/node/17090948. Accessed 13 February 2012.

3. Gopalan C. Nutrition, fertility and reproduction. Proc Nutr Soc India. 1973;14:58.

4. Tripathi MS, Sharma V. Assessment of nutritional status of pre-schoolers in slum areas of Udaipur city. Indian J Publ Health. 2006;50(1):33-4.

5. World Health Organization. Child health research: a foundation for improving child health. In: WHO, eds. Global Forum for Health Research. Geneva: WHO; 2002: 3-30.

6. Briend A, Dykewicz C, Graven K, Mazumder RN, Wojtyniak B, Bennish M. Usefulness of nutritional indices and classifications in predicting death of malnourished children. Br Med J. 1986;293:373-5.

7. Vella V, Tomkins A, Ndiku J, Marshal T, Cortinovis I. Anthropometry as a predictor for mortality among Ugandan children, allowing for socio-economic variables. Eur $\mathbf{J}$ Clin Nutr. 1994;48:189-97.

8. WHO Multicentre Growth Reference Study Group. WHO child growth standards: length/height-for-age, Weight-for-age, Weight-for-length, Weight-forheight and body mass index-for-age: methods and development. In: WHO, eds. Child Growth Standards. Geneva: World Health Organization; 2006: 1-312.
9. Avachat SS, Phalke VD, Phalke DB. Epidemiological study of malnutrition (under nutrition) among under five children in a section of rural area. Pravara Med Rev. 2009;1(2):20-2.

10. Gupta VM, Shukla KK. Epidemiological correlates of PEM in pre-school children. Indian J Prev Soc Med. 1992;23(1):27-31.

11. Dattatraya Dinna Bant. Prevalence of protein energy malnutrition among Aganwadi children's of Hubli, Karnataka. J Nutr Res. 2013;1(1):11-3.

12. Verma R, Khanna P, Gaur D, Meena, Prinja S. Assessment of nutritional status and dietary intake of pre-school children in urban pocket. Int $\mathbf{J}$ Epidemiol, 2007;6(1):9.

13. Harisankar, Shraddha Dwivedi, S. B. Dabaral, D. K. Walia. Nutritional status of children under 6 years of age in rural areas of Allahabad district of Uttar Pradesh. Indian J Prev Soc Med. 2004;35(3\&4):15662.

14. Ahmed E, Khalil S, Khan Z. Nutritional status in children (1-5 years): a rural study. Indian J Community Health. 2011;23(2):84-6.

15. Swami HM, Thakur JS, Bhatia SPS, Singh K, Bhan VK, Bhatia V. National immunization day to assess nutritional status of under 5 in Chandigarh. Indian J Paediatr. 2000;67(1):15-7.

16. Saxena N, Nayer D, Kapil U. Prevalence of underweight, stunting and wasting. Indian Paediatrics. 1997;34:627-31.

17. Joshi HS, Joshi MC, Singh A, Joshi P, Khan NI. Determinants of protein energy malnutrition in 0-6 years children in rural community of Bareilly. Indian J Prev Soc Med. 2011;42(2):154-8.

DOI: 10.5455/2349-3291.ijcp20140804

Cite this article as: Choudhary TP, Chandra Sekhar K, Uma Maheshwara Rao K, Vallepalli C, Deotale PG, Gogineni SS. A study on relevance of mid arm circumference measurement among 13-60 months of children at urban field practice area of Alluri Sita Ramaraju Academy of Medical Sciences, Eluru. Int J Contemp Pediatr 2014;1:84-8. 